NBER WORKING PAPER SERIES

\title{
USURY CEILINGS, RELATIONSHIPS AND BANK LENDING BEHAVIOR: EVIDENCE FROM NINETEENTH CENTURY NEW YORK
}

\author{
Howard Bodenhorn \\ Working Paper 11734 \\ http://www.nber.org/papers/w11734
NATIONAL BUREAU OF ECONOMIC RESEARCH
1050 Massachusetts Avenue
Cambridge, MA 02138
November 2005

\begin{abstract}
I thank the staff of the Jefferson County Historical Society for generously making the original manuscript records available to me. I thank Hugh Rockoff whose work on usury inspired this study and Ed Gamber for his advice on time series procedures. Tim Guinnane, Michael Kelly, Eugene White, seminar participants at Rutgers University and two anonymous referees offered many constructive comments. I also thank Pam Bodenhorn for her assistance in transcribing and coding the data and Lafayette College's Academic Research Committee for financial support. The views expressed herein are those of the author(s) and do not necessarily reflect the views of the National Bureau of Economic Research.
\end{abstract}

(C)2005 by Howard Bodenhorn. All rights reserved. Short sections of text, not to exceed two paragraphs, may be quoted without explicit permission provided that full credit, including $₫$ notice, is given to the source. 
Usury Ceilings, Relationships and Bank Lending Behavior: Evidence from Nineteenth Century

New York

Howard Bodenhorn

NBER Working Paper No. 11734

November 2005

JEL No. N2, N8, G2

\begin{abstract}
$\underline{\text { ABSTRACT }}$
Few pieces of economic regulation are ubiquitous as usury limits. Similarly, few economic principles are as widely accepted as the belief that interference with freely contracted prices leads to market distortions, and many studies of financial markets find that usury limits negatively affect credit availability. This study shows that when no regulatory authority monitors and stands ready to punish violators of the usury limit when intermediaries and borrowers form long-term relationships, banks and borrowers regularly contract for interest rates in excess of the usury ceiling. Time series analysis reveals limited effects on credit availability when market rates exceed the usury ceiling. Crosssectional analysis of individual loan contracts also shows that the positive effect of a long-term relationship offsets the negative effect of the usury limit on credit availability.

Howard Bodenhorn

Department of Economics

Lafayette College

Easton, PA 18042

and NBER

bodenhoh@lafayette.edu
\end{abstract}




\section{Usury Ceilings, Relationships and Bank Lending Behavior: \\ Evidence from Nineteenth-Century New York}

\section{Introduction}

Few pieces of economic regulation are as ubiquitous across time and space as interest rate ceilings or usury laws. The code of Hammurabi, the Old Testament, Vedic and Roman law, and the Koran among other religious and legal codes, banned usury (Glaeser and Scheinkman 1998). In an American context, nearly every U.S. state imposed a usury limit at some point in its history and a usury provision was included in the National Currency Act of 1863 (Rockoff 2003). Given the ubiquity of usury prohibitions, the taking of interest and usury absorbed the minds of some of history's greatest thinkers. Economic and political philosophers from Aristotle to Aquinas, from Locke to Smith, and from Bentham to Keynes all weighed in on the subject. Even if we do not fully understand the economic ramifications of usury laws, we have a reasonably good appreciation for the motives underlying them. Usury ceilings were established to curb monopoly power, to protect small borrowers, to discourage profligacy and, perhaps most importantly, to influence the allocation of resources (Riemersma 1952, Blitz and Long 1865, Avio 1973).

Although the most common defenses of usury laws by religious and political leaders are that they protect small borrowers from the depredations of unscrupulous lenders when interest rates rise markedly and that they redirect credit to sectors of the economy deemed meritorious, such 
regulations may distort markets so that the good intentions of assisting meritorious agents or sectors may not be achieved (Tuccillo 1977). When usury ceilings become binding, banks unable to equate supply and demand through price increases will adjust other terms of the loans to push the market toward equilibrium. ${ }^{1}$ Substantial changes in the nonprice terms of credit can actually make small borrowers worse off because they are either cut off from credit or they are driven to other, sometimes disreputable, sources of credit. Interest rate ceilings force some borrowers into the hands of lenders who employ inefficient and extra-legal methods of enforcement and collection (Masciandaro 2001, 2002). In less extreme instances, a binding usury law encourages the expenditure of resources in identifying loopholes to exploit or camouflage illegal behavior (Nathan 1980). The implication is that high-risk or low-wealth borrowers are excluded from credit markets when freely fluctuating market rates rise above the usury limit.

Although Wright (2002) argues that banks were reluctant to violate usury laws because doing so placed their corporate charter at risk, Davis (1960) finds that at least some banks chose to violate the legal interest-rate ceiling, if not with impunity, at least regularly. The relevant question is: Under what circumstances would a bank choose to violate the law? Or, to recast the question in economic terms: When would a bank find it profitable to violate the law? A related question is: What effect did the bank's choice to violate the law, when it chose to do so, have on credit availability?

The early literature holds that binding interest-rate ceilings introduce market distortions, but much of this literature assumes that banks observe the law. Indeed, in their influential analysis of credit rationing, Jaffee and Modigliani (1969) assume that a combination of usury laws,

\footnotetext{
${ }^{1}$ See Blitz and Long (1965), Ostas (1976), Nathan (1980), Villegas (1989), Wolken and Navratil (1981), Peterson (1983), and Rockoff (2003).
} 
considerations of good will, and social norms make it unlikely that banks will charge any borrowers an exceptionally high or usurious rate. Given that the usurious transaction was mutually beneficial at its inception, a bank's decision to violate the usury limit may have mitigated the negative effects of high rates on credit availability. But even if a higher rate compensated a bank for default risk, its

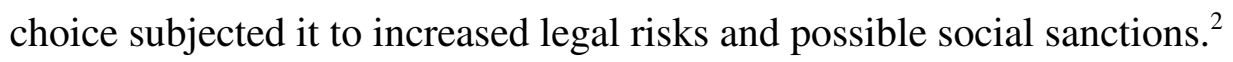

Temin and Voth (2005) follow the tradition of assuming that banks observe usury limits and that their decisions to do so alter lending behaviors. This study adopts a different approach. Following Becker (1968), I assume that banks engage in illegal activity when the expected benefits of violating the usury limit exceeds the expected costs. This study also differs from Temin and Voth in that they exploit a one-time, exogenous natural experiment - a decrease in the usury ceiling - to study the consequences of financial repression. This study makes use of dozens of small, exogenous natural experiments, namely, periods when market interest rates rose above the usury limit. ${ }^{3}$ Movements in market rates in excess of the usury limit were, from the individual banks' points of view, exogenous events because banks operated in competitive markets and had no influence on market rates or the ceiling rate. As rational agents, they responded to both.

Using time-series and cross-sectional techniques, this article investigates how New York's seven percent usury ceiling influenced the Black River Bank's lending behavior. The data reveal

\footnotetext{
${ }^{2}$ It is interesting to note that the banker discussed here was characterized by local historians as something of a Scrooge, a man more concerned with profit than with community (Emerson 1898). It appears that his legacy, at least, suffered from social sanctions even if he did not during his lifetime.

${ }^{3}$ In the mid-nineteenth century, market interest rates on short term loans could exceed the usury limit because the law of negotiable instruments drew distinctions between primary and secondary securities markets. Any lender originating a loan had a legal duty to observe the usury limit. If that lender later decided to sell the loan in a secondary market, such as the active secondary market in bills of exchange, the transaction price might be low enough to imply a usurious interest rate, but not violate the law. That the law recognized this difference adds additional support to the contention that usury laws were designed to protect small, unsophisticated borrowers. Traders in secondary markets were more likely to be sophisticated agents.
} 
what some historians have long suspected, namely, that early American banks regularly violated usury laws (Horowitz 1977). Surviving records show that while the ceiling rate often proved binding the bank routinely charged rates in excess of the legal limit. It was not unknown for borrowers to pay twice, even thrice, the legal limit. Despite its flagrant violations of the law, no evidence that borrowers charged usurious rates sued the bank to escape their debts and recover the usury has been uncovered. $^{4}$

What effect did high market rates have on credit availability? The time-series evidence, based on more than 29,000 loan contracts, finds that when secondary market rates on short-term loans rose above the usury limit neither the number of loans nor aggregate lending changed in any meaningful way. Average and median loan size increased while average and median maturities declined. Although aggregate lending behavior was little changed by high market rates, the composition of the loan portfolio was changed, mostly to the detriment of small, subprime borrowers.

Cross-sectional results address the issue of when the bank chose to violate the usury ceiling and why borrowers did not sue. They did not sue because they valued the long-term relationships they had formed or expected to form with the bank. Long-term relationships between borrowers and bankers were valuable because they encouraged the bank to collect and use proprietary information about borrowers, which allowed banks to offer more attractive loan terms than they could have without that information. If a borrower sued on a usury charge to escape his or her debt, he or she effectively terminated a relationship. The cross-sectional results show that the relationship effect

\footnotetext{
${ }^{4}$ A careful survey of the bank's records, including its discount books (discussed below) and letter books, revealed no mentions of suits filed against it for usury. The bank's clerks routinely made marginal notations in the discount books about renewals, extensions, and protest for non-payment, so it seems likely that notations concerning suits would have been made. Similarly, no outgoing correspondence was found concerning legal cases involving usury. Local court records from the period were not consulted.
} 
outweighed the usury effect. Borrowers paying usurious rates received smaller loans, which reflects the bank's desire to limit its default and legal risks. But even among those borrowers paying usurious rates, those with longer borrowing histories were less subject to credit rationing. Thus, the future value of a banking relationship was worth more to a borrower than the one-time gain to be had from a successful pleading of usury. While a rigidly enforced usury law may be one component of financial repression (McKinnon 1973, Shaw 1973), New York's self-enforcing (or tort) statute cannot be characterized as truly repressive. ${ }^{5}$

The next section summarizes New York's usury law. Section 3 offers a conceptual approach to bank behavior in the face of a binding usury constraint based on Becker's (1968) economics of crime model. The fourth section describes the data. Section 5 reports the results of both the timeseries and cross-sectional results, which reveal how New York's interest-rate ceiling influenced on the bank's lending behavior. Finally, section 6 discusses the results and concludes.

\section{A Brief History of New York's Usury Law}

The first law prohibiting usury in New York, enacted in 1717, established a legal maximum of 6 percent (Blydenburgh 1844, pp. 8-9). It was raised to 8 percent the following year, where it remained until it was reduced to 7 percent in 1737 . The 1737 statute not only lowered the legal maximum, it imposed more severe penalties. If a plaintiff successfully demonstrated usury, he or she recovered three times the loan principal. A 1787 statute retained the 7 percent limit, but reduced the penalty (Romano 1989). Under the 1787 statute, a plaintiff proving usury was relieved from repaying

\footnotetext{
${ }^{5}$ A self-enforcing statute is one in which the wronged party must bring suit to recover damages specified by the law. Self-enforcing statutes, even when they involve a criminal act, thus differ from those in which a regulatory body oversees transactions and enforces compliance.
} 
the principal and recovered the excess of interest over the legal maximum. Thus, the usurer was left with no more than an amount equal to seven percent annualized interest on the original principal.

According to Blydenburgh (1844), the subsequent 50 years of case law so completely stripped the statute of force that there was wide support in the 1837 legislative session to repeal the law altogether. But before the repeal bill was passed, the panic of 1837 erupted. Rapidly rising interest market interest rates on good bills of exchange approached or exceeded 20 percent in every commercial center from Boston to New Orleans (Bodenhorn 1992). Rather that repealing the 1787 act, the legislature reversed course and passed an act that not only maintained the 7 percent limit, but increased the penalties for violating it. In addition to the civil penalties of forfeiting the loan principal and excess interest, violators were also subject to criminal penalties, including a maximum fine of $\$ 1,000$ or a prison term not exceeding six months, or both. The 1837 act also rescinded many of the exceptions developed under the preceding 50 years of case law.

Romano (1989) reports that remonstrances against the law commenced shortly after its enactment. The only substantive statutory change in New York's usury law in the antebellum era occurred in 1850 when the Dry Dock Company, a bank operating in New York City, successfully claimed usury to avoid repaying $£ 50,000$ in sterling bills rediscounted from the American Life Insurance \& Trust Company because the latter had discounted the bill at a more than seven percent (Boyes and Furnish 1984). The public outcry was such that the legislature created a corporate exception so that no other sophisticated borrower could shield itself from its obligations by hiding behind the state's usury statute. Clearly, legislators believed the law was designed to protect unsophisticated borrowers. Borrowers with some market savvy, and all corporations, were bound 
to pay whatever rate they contracted for. ${ }^{6}$

As a result of the 1850 legislative investigation into the Dry Dock case, a senate committee recommended sweeping revisions to the law. The committee found the severity of the punishments imposed by the 1837 act excessive, which made courts reluctant to enforce it (New York Senate 1851). Indeed, the committee could not identify a single individual indicted by a grand jury on a criminal usury charge, but argued that borrowers routinely agreed to usurious loans only to later invoke the law, as the Dry Dock had, to avoid repayment. In the committee's opinion the law, instead of protecting the powerless from the powerful, worked to the disadvantage of legitimate, but less than high-grade borrowers who were closed out in periods when market rates exceeded the statutory limit. One contemporary observed that frustrated borrowers were more likely than frustrated lenders to petition the legislature for repeal or relaxation of the usury ceiling and penalties (New York Times, 10 March 1852). Despite repeated calls for amending the law, it stood unchanged until 1886 when the most punitive aspects of the law were eliminated (Romano 1989).

Although some contemporaries (Blydenburgh 1844) and historians (Horowitz 1977) portray the usury law as largely toothless, recurrent attempts to repeal or amend it suggest otherwise. Efforts to change a law are costly, as are political exertions to retain it. That such costs were borne on both sides suggests that the law had either allocative or distributional effects or both. A full accounting of the winners and losers from the usury ceiling would require an exercise in political economy well beyond the scope of this study, but it seems probable that the driving forces behind the 1837 usury act will be found in the Jacksonian egalitarianism that took root in New York in the late 1820s and

\footnotetext{
${ }^{6}$ Of course, case law precedents that exempted secondary security transactions from the usury limit had the same effect. Most buyers and sellers in secondary markets were professional traders and dealers and were well aware of the consequences of their actions.
} 
bloomed in the 1830s (Bodenhorn 2006). Imprisonment for debt was abolished in New York in 1831. The usury law was stiffened and the prohibition on private banking was lifted in 1837 . Free banking was enacted in 1838. All four changes were designed to reduce the cost and increase the availability of credit.

Of course, modern economic analysis tells us that attempts to influence the allocation of credit with price ceilings will be frustrated by alterations in the nonprice terms of credit, but contemporaries supporters of usury limits relied on venerable beliefs that usury limits protected the poor, discouraged the profligate, and the relieved the unfortunate (Reed and Bekar 2002). Evidence presented below is consistent with the modern interpretation. Banks and borrowers found methods to mitigate the consequences of binding usury limits, either through changes in the nonprice terms of credit, or in selectively violating the law. The next section explains when and why a bank would opt to violate the law, and why borrowers charged usurious rates did not regularly sue the usurer.

\section{Conceptual Apparatus and Empirical Strategies}

The problem facing the lender contemplating the granting of a usurious loan can be posed as an application of the Becker's (1968) model of the economics of crime, in which agents will engage in illegal or criminal activity if the expected gain from the criminal act exceeds the agent's reservation wage. Applying Becker's logic, the problem can be reformulated so that a bank will supply a loan at a rate above the legal maximum when the expected returns from doing so exceed the bank's reservation return, or the return it would realize if those same funds were extended to a different borrower at or below the usury limit (or invested in some other legal security).

In this case, the banker receives a pecuniary benefit from engaging in usury $\left(r_{u} L\right)$, which is 
the usurious interest rate times the loan amount. A banker faces a potential cost from engaging in usury in that he may be sued and lose, and be legally required to pay an amount $\mathrm{C}$. The probability that he may fail to provide an adequate usury defense can be represented by $\rho$. If the banker is riskneutral, the expected cost of extending a usurious loan is $\rho C$. The expected returns are then $r_{u} L-$ $\rho \mathrm{C}$. This return will be compared to the return from extending the same amount of credit at a legal rate, which can be denoted as $r_{1} L$, where $r_{1}$ represents the legal or ceiling rate. The banker will engage in usury if: $r_{u} L-\rho C>r_{1} L$.

If every borrower was identical, then every loan would pay either $r_{u}$ or $r_{1}$. A more realistic situation is one in which interest rates on usurious loans equal $r_{1}+x$, where $x$ is distributed according to a density function $\mathrm{f}(\mathrm{x})$ and a cumulative distribution function $\mathrm{F}(\mathrm{x})$ (Glaeser 1999). ${ }^{7}$ Now we can rewrite the previous choice decision as: $\left(r_{1}+x\right) L-\rho C>r_{1} L$. The marginal usurious loan is found such that $\left(r_{1}+x\right) L-\rho C=r_{1} L$. Rearranging terms yields loan size as a function of the costs and benefits of usury: $L=\rho C / x$. Standard differentiation tells us that loan size decreases in the extent of usury $\left(\delta \mathrm{L} / \delta \mathrm{x}=-\rho \mathrm{C} / \mathrm{x}^{2}<0\right) .{ }^{8}$ Thus, as market rates rise above the usury level, borrowers whose

\footnotetext{
${ }^{7}$ It must be remembered that even in competitive markets, banks do not take the interest rate as given and the law of one price is likely to be violated in markets where quality depends on price (Stiglitz 1987, p. 4, 11). The literature on relationship lending also contemplates the possibility that lenders in nominally competitive markets will charge different borrowers with similar observable characteristics different prices. Banks can capture rents through informational advantages gained through repeated interactions with individual borrowers. See Elyasiani and Goldberg (2004) for a recent survey.

${ }^{8}$ Under New York's usury law, the penalty $\mathrm{C}$ was loss of principal, so that $\mathrm{C}=\mathrm{L}$. But there were other costs as well, including court costs, attorney's fees, and so forth. Let those additional costs be independent of loan size and be equal to $\mathrm{k}$. Under the assumption of risk neutrality, the expected costs of usury are then $\rho(\mathrm{L}+\mathrm{k})$. Substituting this into the above equation, solving, and differentiating yields $\delta \mathrm{L} / \delta \mathrm{x}=-\rho \mathrm{k} /(\mathrm{x}-\rho)^{2}<0$, if $\mathrm{x}>\rho$. So long as the excess of the market rate $(0 \leq x<\infty)$ exceeded the expected probability of prosecution $(0 \leq \rho \leq 1)$, higher market interest rates led to smaller loans. This specification increases the extent of the usury ( $\mathrm{x}$ ) necessary to decrease loan size, however. Byldenburgh (1844) and the New York Senate (1851) committee believed that $\rho$ was quite small so that the condition here and in the text above are effectively equivalent. Under different legal regimes, they need not be so.
} 
risk characteristics imply a higher rate (i.e., $\mathrm{x}>0$ ) will receive smaller loans, while those whose characteristics imply a lower $(\mathrm{x}<0)$ rate will receive larger loans. This result is also consistent with models of credit rationing. ${ }^{9}$ As Jaffee and Modigliani (1969, p. 865) note, even in the presence of flexible rates, banks may opt to restrict loans because with default risk (increasing in $\mathrm{x}$ ), reducing the loan size increases the expected rate of return on the loan by reducing the expected loss resulting from default. The implication is that borrowers in the usurious market will receive smaller loans than borrowers in the sub-usurious market, but they are not completely rationed. The principal empirical prediction concerning loan characteristics and usury is that borrowers paying usurious rates should receive smaller loans. It also implies that as the gap between the market rate and the usury limit increases, loan size will decline.

The question arises: Why would a borrower charged a usurious rate not immediately file a tort suit to be released from the debt? Legal proceedings, to be sure, are uncertain and potentially expensive, so that the probability of prevailing and benefitting from a case was less than unity. But banks kept detailed records - day books and ledgers - that contained abundant evidence of the crime. It would appear that prevailing in a usury case would be relatively straightforward and prone to few risks and low costs. Subpoenaing the records was simple enough and the bank had few incentives, given the information contained in them, to destroy the records. One possible explanation for the dearth of usury suits was that the long-run costs to a borrower from winning (or even instituting) a usury case exceeded the short-run benefits of winning such a case. What the plaintiff risked in instituting a usury suit was the loss of the existing bank-borrower relationship.

\footnotetext{
${ }^{9}$ There is the possibility that the variable is partly capturing a credit-rationing effect, but there is no reason to believe that the (fixed) usury limit was established close to the (changeable) rate at which banks would engage in significant credit rationing.
} 
The growing literature on relationship banking centers on the issue of whether a long-term bank-borrower relationship enhances an informationally opaque borrower's access to credit or the terms under which credit is extended..$^{10}$ Relationship lending is best defined as a long-term implicit contract between a bank and a borrower (Elsas 2005). Through repeated interactions with a borrower, a relationship lender gathers valuable private information about the borrower by observing deposit flows, loan repayments and internal accounting information, and thereby acquires knowledge about the business plans and projects of the borrower (Elyasiani and Goldberg 2004). Access to such information gives the relationship banker a competitive advantage in supplying credit and monitoring a borrower's behavior after the loan is made.

Long-term ties provide benefits to both parties, but the most important from the borrower's viewpoint are increased credit availability, intertemporal smoothing of credit flows, and more efficient allocation decisions during a credit crunch. The borrower may incur costs from becoming involved in an exclusive long-term relationship with a lender. Sharpe (1990) and Rajan (1992), for instance, argue that a growing informational advantage by an existing relationship lender gives it market power, which may raise the borrower's cost of credit. But even this effect can be mitigated through long-term contracts negotiated ex ante (von Thadden 1995).

The most commonly used empirical proxies for relationship lending are relationship duration and exclusivity. If durable relationships generate more or higher quality private information, loan terms, especially credit availability, should improve over the life of the relationship. The functional association between credit availability and relationship duration need not be monotonic, however.

\footnotetext{
${ }^{10}$ Recent reviews of the literature include Boot (2002), Ongena and Smith (2000), and Elyasiani and Goldberg (2004).
} 
There may be a considerable start-up period during which the bank learns about the borrower. Moreover, the value of old information may decline with changing market conditions. Finally, as with any other productive resource, the marginal product of more information is likely to decrease at some point.

To the extent that relationships are valuable to borrowers because they mitigate the effects of credit rationing, even during periods of high or rising rates, borrowers will be unwilling to sever the relationship by instituting a usury suit. If the borrower values a continuing relationship and the costs of establishing a new one are nontrivial, borrowers may pay (either gladly or grudgingly) rates in excess of the usury ceiling and not file a suit. The relationship literature predicts that market rates in excess of the legal rate will have modest effects on credit availability measured by loan size or loan maturity, after controlling for the bank-borrower relationship. A durable relationship is likely to drive the bank's expectation of a usury filing toward zero, with the result that the usury law was a dead letter in instances when both parties valued the on-going relationship and could credibly signal an intent to maintain the relationship. Nevertheless, banks had to be wary of borrowers without borrowing histories and be aware of those whose short-term gains from severing a relationship might lead them to institute a usury suit. Section 5 provides empirical estimates of the effects of relationships and the usury limit on credit availability. The next section describes the data.

\section{Data}

The data, consisting of records of more than 29,000 loans made between November 1845 and April 1859, come from the Black River Bank of Watertown, New York (Black River Bank, Discount Book \#2, Discount Book \#3). Loveland Paddock opened the bank in late 1844 under the terms of 
New York's 1838 Free Banking Act. Although Paddock was a dry goods merchant when he opened the Black River Bank, he had extensive prior banking experience. He became a director in the Jefferson County Bank of Watertown in 1828. When the Sacket's Harbor Bank was established in 1834, he purchased shares and became a director of that bank as well. In 1839, even while he was still served as director of the Jefferson County Bank and the Sacket's Harbor Bank, he joined with several men in organizing the Bank of Watertown as a free bank. Paddock served as its first president (Albany Argus, 17 June 1840). He continued as president until 1842, when he resigned and sold his shares. He continued as a dry goods merchant until 1844, when he liquidated his merchandise, purchased \$40,000 in mortgages and New York State bonds, which he deposited with the state comptroller, and announced the opening of the Black River Bank (hereafter BRB) of Watertown (Albany Argus, 19 February 1845).

Because Paddock controlled 90 percent of the bank's shares, with the remaining 10 percent divided between two of this three sons, the BRB was legally designated an "individual" bank, which under New York's free banking act had all the rights, privileges, and obligations of any other free bank, but was more limited partnership than corporation. ${ }^{11}$ The shares were closely held and never known to be traded (Emerson 1898, p. 336). Paddock's eldest son served as the bank's vice president. His second son was cashier.

The first publicly reported account for the BRB is a balance sheet for February 1845. At that time the bank had only $\$ 28,000$ in outstanding loans and discounts and about $\$ 95,000$ in total assets, which meant that it was dwarfed by the Jefferson County Bank, which had \$291,000 in outstanding

\footnotetext{
${ }^{11}$ In later state documents (see, for example, New York State Assembly 1856), the bank was listed as an Association (i.e., joint-stock company) instead of an Individual bank. It is unclear why this change in official designation occurred, but the change did not have any practical implications for the bank's operations.
} 
loans and discounts and $\$ 510,000$ in total assets (Albany Argus 19 February 1845). Although small in comparison to the Jefferson County Bank, the BRB was already comparable in size to another individual bank and about half the size of the Bank of Watertown. The BRB would quickly surpass the Bank of Watertown in loans and assets, which may explain why Paddock sold his interest in that bank and started his own. He had ambitions for a larger bank.

By 1850 the BRB was the second largest bank in Watertown and was larger than many other individual or free banks in the state. Measured by outstanding loans in 1850, the BRB was more than three times the size of the average individual bank. It was about half again as large as the average of all individual and free banks; and it was nearly the same size as the average of all banks (individual, free, and chartered) in New York, outside New York City (Albany Argus, 25 November 1850). By 1860, the BRB was about 60 percent larger than the average New York bank (New York Assembly, 1862).

The available evidence suggests that the BRB was a prominent financial intermediary in a dynamic local economy. Between 1848 and 1860 the value of loans granted by the bank grew at an average annual rate of 6.7 percent, or at more than twice the annual rate of capital formation or growth in manufacturing output in the local economy (U.S. Census Office 1854; U.S. Census Office 1866). By 1860 the BRB was one of seven commercial banks in Watertown. It was a prominent, but not dominant, lender in the local market. It had extended about 26 percent of the total credit given by the city's banks in 1855, and a total of about $\$ 15.6$ million in new loans between November 1845 and April 1859.

How representative was the BRB of banks in the region? As with any case study, this is a difficult question to answer. In many regards, the bank was typical. Individual banks owned by one 
or a few entrepreneurs and organized under the state's free banking law were common, though the BRB grew larger than most. Although individual and free banks were established in communities large and small throughout the state after 1838, many located in emerging commercial and industrial centers along the Erie Canal, such as Lockport and Syracuse, or along Lake Ontario in towns such as Rochester, Buffalo and Oswego. Located in Watertown, just a short distance from the convergence of the Saint Lawrence River and Lake Ontario, the BRB resembled the latter. In other ways, the BRB may be atypical. Kahn (1985) estimated the average life expectancy of a NewYork free bank to be 21 years. The BRB survived for 36 and liquidated voluntarily rather than ended in bankruptcy. Traditional interpretations of nonurban antebellum banks also hold that banks held an inefficiently large percentage of repeatedly renewed agricultural mortgage loans (Hammond 1957, Redlich 1969). The available evidence from the BRB suggests that less than 10 percent of loans were granted to farmers. Less than 2 percent of loans were ever renewed. Mortgage loans were highly unusual. Until detailed records of other banks - which are few and difficult to access - from the period are uncovered and transcribed, it is impossible to know the extent to which the BRB was typical. By all outward appearances, however, the BRB was not extraordinary.

A second legitimate basis for determining the BRB's representativeness may be to compare it to a peer and competitor - the Jefferson County Bank, a free bank also located in Watertown. The Jefferson County Bank had a larger capital $(\$ 199,000)$ than the BRB $(\$ 125,000)$, but was less efficient in leveraging its capital into earning assets. In December 1854 , the BRB had $\$ 368,755$ in outstanding loans and discounts and held $\$ 147,780$ in bonds and mortgages compared to $\$ 495,446$ and $\$ 33,821$ for the Jefferson County Bank. Thus, the loan-capital ratio for the BRB at 2.95 exceeded the 2.48 ratio at the Jefferson County Bank, and far exceeded the 1.70 ratio for all New 
York State banks. The earning asset-capital ratio at the BRB (4.13) exceeded that of the Jefferson County Bank (2.65) by a wide margin and the statewide average (2.03) by a wider one yet. ${ }^{12}$ The BRB was much more aggresive in leveraging its capital into earning assets. It was similarly more aggressive in leveraging its specie holdings into note issues (New York State Assembly 1856). Although the evidence suggests that while the management of the BRB was more willing than many to leverage its capital and specie, these were not foolhardy bankers. Less than 1 percent of its loans were ever protested for nonpayment at maturity. We may never know how representative this bank was, but its owners appear to have been better than average entrepreneurs and bankers.

Among the bank's handwritten records are two discount books, which include all the information recorded about each loan. Both discount ledgers include the name of the borrower; the date of the loan; the date the loan matured; the loan amount; and the total interest charge. In addition to this information, the second extant ledger (BRB Discount Book \#3) also recorded the names of all endorsers (consignors) on each note or bill, and indicated whether the loan was a renewal of a previously granted loan. Given the massive amount of information involved, the names of consignors were not transcribed, but the number of endorsers was. Annualized rates of interest are calculated as $\mathrm{r}=($ discount in $\$$ / loan amount in $\$) *(365$ / days to maturity).

Figure 1 plots total monthly lending by the BRB. The bank's continuing growth up to the Panic of 1857 is obvious, as is the more pronounced seasonal pattern of lending beginning in the early 1850s. Given the immense influence of the panic on the bank's lending behavior, the empirical analysis will consider the bank's lending behavior only between November 1845 and August $1857 .^{13}$

\footnotetext{
${ }^{12}$ Earning assets include loans and discounts plus public stocks and mortgages securing banknote issues.

13 A study of the bank's lending behavior during the panic is provided in Bodenhorn (2003).
} 
Because the focus of this article is on interest rates, Figure 2 plots the monthly average and median annualized interest rates charged by the bank between 1845 and 1859. By the early 1850s, average rates consistently exceeded the seven percent usury limit and become increasingly volatile. Between 1845 and 1850, median rates gradually climbed toward the seven percent limit, and then remained there until the panic. That the median loan rate was at the usury limit and that the annual modal loan rate between 1846 and 1857 was between 6.95 and 7.00 percent in 8 of 11 years is evidence that the usury ceiling constrained the bank's behavior much of the time. ${ }^{14}$ Indeed, between January 1855 and August 1857 (to exclude the panic period), the modal rate for all four years was exactly 7.00 percent, and nearly half of all loans paid interest rates between 6.95 and 7.05 percent. Given the movements in short-term commercial paper rates over the same period, the stability and the value of the modal bank rate on short-term loans is more likely the consequence of the legal restriction than market forces.

Despite the constraint imposed by the usury limit in many instances, the bank routinely charged rates in excess of the legal ceiling. Table 1 reports the frequency distribution of loans in one percentage-point increments. A slight majority (56.6 percent) of the more than 29,000 loans were extended at rates between 6.00 and 6.99 percent. The second most common interval (7.00 to 7.99), however, implies that more than one-third of the bank's loans were extended at interest rates that exceeded the statutory limit by less than 1 percentage point. But another four percent of all loans

${ }^{14}$ Loans made at rates between 6.95 and 7.05 percent are considered to have been made at the usury limit of 7.00 percent. Consider the following hypothetical. A borrower approached the bank with a 30-day bill with a face value of $\$ 100$. If the bank imposed a $\$ 0.57$ discount, its effective loan rate was $6.935 \%$. If it imposed a $\$ 0.58$ discount, its loan rate was $7.057 \%$. Because the bank could not divide pennies, there was a band around the 7 percent limit within which a bank charging the maximum legal amount would lie. The longer the maturity and the larger the amount, the narrower the band. On a 90-day, $\$ 100$ loan, for example, a discount of $\$ 1.72$ implies a loan rate of $6.976 \%$; and a discount of $\$ 1.73$ implied a rate of $7.016 \%$. 
were made at rates in excess of 8 percent. In all, the bank made 12,140 loans - or 41.7 percent of the total - at rates in excess of the statutory interest ceiling. One loan paid a 70.02 percent interest rate. For the BRB, the legal interest ceiling was not irrelevant, as it seemingly constrained the rate at which it made a large fraction of its loans. But the bankers also had little compunction about charging borrowers interest at rates in excess of the limit. The next section addresses the implications of the ceiling for credit availability and the conditions under which the bank chose to charge rates in excess of the usury limit.

\section{Empirical Results}

This section uses two types of multivariate empirical techniques to uncover the consequences of New York's usury law on the lending behavior at the BRB. First, time-series tests correlate monthly levels in the total number of loans, the volume of loans, the average and median loan size, and the average and median loan maturities with the difference between the current market rate on short-term commercial paper and the statutory ceiling. In later subsections, cross-sectional techniques are used to identify differences in the characteristics of loans paying usurious and nonusurious rates.

\subsection{Time-series Analysis}

To investigate how the seven percent interest rate ceiling influenced lending behavior, six separate dependent variables are generated from more than 29,000 loan contracts: the number of loans granted each month; the aggregate dollar value of loans granted each month; monthly average and median loan size; and monthly average and median loan maturity. The measure of the market 
rate used here is the rate on short-term commercial paper traded in New York City. Banks, including the BRB held large amounts of commercial paper, which was mostly high-grade domestic bills of exchange with an attached bill of lading. Some was purchased by banks in the secondary market through brokers and correspondents; some was originated by the banks themselves and sold on their behalf through the same correspondents (Bodenhorn 2000). Further, because New York's commercial paper market was a mostly secondary market - that is, few loans originated in this market - lenders were not subject to the state's usury restriction. A long tradition of case law in New York and elsewhere held that secondary lenders (or buyers of commercial paper) were not subject to the statutory usury penalties, so that traders were free to buy and sell commercial paper at whatever rate cleared the market (Blydenburgh 1844, p. 59). ${ }^{15}$ Thus, when market rates rose above the statutory limit, banks that originated loans did not engage in wholesale violations of the usury law, as the large number of loans made by the BRB at the usury limit attest. They did, however, violate the law selectively (more on this below). The issue considered in this section is the effect that a market rate in excess of the statutory limit had on the BRB's overall lending behavior and portfolio choice.

The crime model of usury implies that the idiosyncratic element of the individual loan rate, $\mathrm{x}$, around the legal limit $\left(\mathrm{r}_{1}\right)$ will be a function of the market rate, signified here as $\mathrm{R}_{\mathrm{NYC}}$. Recall, as well, that the model predicts that as $\mathrm{x}$ increases the size of the marginal usurious loan will decrease. If, as the market rate increases above the statutory ceiling, the bank is induced to extend a larger number of smaller usurious loans, average loan size will actually increase as the bank balances its

\footnotetext{
${ }^{15}$ Case law in Pennsylvania was similar. As early as 1811, a Pennsylvania court held that "a fair purchase may be made of bond or note, even at twenty or thirty per cent. discount, without incurring the danger of usury" (quoted in Bodenhorn 2000, p. 148).
} 
risks by offering ever larger loans to low-risk customers in the subusurious market (Nathan 1980). At the BRB, for instance, the average value of all loans charged a rate between 0.01 and 7.00 percent was $\$ 554$; the average value of loans paying between 7.01 and 70.01 was $\$ 463$. With a z-value of 9.6, the difference in the means of usurious and nonusurious loans is statistically significant.

The legal risk effect (fear of being sued) will be reinforced by a credit rationing effect (fear of default) when market rates are high. When quality is negatively related to price, as with bank loans, higher rates will induce banks to contract lending in the high-price (and high-risk) market when they perceive the default risks of such assets to have increased. As Jaffee and Modigliani (1969, p. 865) note, reducing the loan sizes for high-rate borrowers will increase the expected return by reducing expected default costs. Thus, when the opportunity cost due to an increase in market rates rises and lenders are unable to raise returns by raising rates, they will find it profitable to raise their returns by upgrading the quality of their portfolio by shifting funds away from riskier customers. The empirical prediction, then, for aggregate loan behavior is that increases in the market rate above the usury limit will result in larger average and median loan sizes. This result is fully consistent with the diminishing size of individual loans extended at usurious rates. A second prediction is that loan maturities will fall as banks adjust nonprice loan terms in response to their inability to fully adjust prices to compensate them for accepting added legal and default risk (Ostas 1976).

The first step in the time-series analysis is to determine whether the individual series are stationary. Phillips-Perron unit root test statistics are presented in Table 2 . The statistics reveal that the null hypothesis of a unit root can be rejected in every series at the $1 \%$ confidence level. Each Phillips-Perron regression includes a trend term and four lags of the dependent variable. Because the 
individual series are stationary in levels, the empirical analysis is conducted using levels rather than first differences.

To test the hypothesis that a statutory interest rate ceiling influenced lending behavior at the $\mathrm{BRB}$, the independent variable of interest in each case is the difference between the rate on "good" commercial paper in New York City and the seven percent usury limit (e.g., $R_{\mathrm{NYC}}-\mathrm{R}_{\text {limit }}$ ). Over the 142 month period between November 1845 and August 1857, the market rate on good commercial paper exceeded the usury limit by one-quarter of a percentage point, or 25 basis points.

The regression specifications also include a time trend and 11 monthly dummies (December is the excluded month) to control for secular and seasonal effects. Lending peaked in the late autumn and reached a low point during the summer. Finally, initial tests uncovered that the disturbances follow a linear autoregressive, moving average specification, so that the estimated regressions take on the following form:

$$
\begin{aligned}
& \mathrm{y}_{\mathrm{t}}=\mathrm{z}_{\mathrm{t}} \beta+\mu_{\mathrm{t}} \\
& \mu_{\mathrm{t}}=\rho \mu_{\mathrm{t}-1}+\theta \epsilon_{\mathrm{t}-1}+\epsilon_{\mathrm{t}}
\end{aligned}
$$

where the $y_{t}$ 's are the dependent variables of interest, $z_{t}$ is a vector of independent variables, $\rho$ is the first-order autocorrelation parameter; $\theta$ is the first-order moving average parameter; and $\epsilon_{\mathrm{t}}$ are white-noise disturbances, assumed to be i.i.d N $\left(0, \sigma^{2}\right)$. Preliminary trials failed to uncover significant higher-order AR or MA terms, so the regressions were estimated as ARMA(1,1) models.

Table 2 reports the regression results. The time trend was economically meaningful and statistically significant in every specification. According to the the estimate, aggregate lending increased by an average of $\$ 1,338$ each month. Average loan size increased by an estimated $\$ 5.27$ per month, and average maturities declined by about 0.17 days per month. Unreported F-tests reveal 
that the monthly dummies were jointly signficant in all six specifications. Generally, individual coefficients on the spring and autumn dummies were individually significant. The ARMA terms were significant in every regression but one. Finally, the effect of the difference between the market rate and the usury ceiling, or $\mathrm{R}_{\mathrm{NY}}-\mathrm{R}_{\text {limit }}$, had small and insignificant effects on aggregate bank behavior (total loans and total dollar value of loans), but had more significant and meaningful effects on average and median loan terms.

An increase in the market rate-usury gap, for instance, had a statistically insignificant and small negative effect on the monthly number of loans. A one percentage point increase in the gap implies a decrease of just three loans per month. Similarly, the results reveal that a one standard deviation increase in $\mathrm{R}_{\mathrm{NY}}-\mathrm{R}_{\text {limit }}$ reduced the average aggregate value of monthly loans by 0.45 percent - a trivial amount by almost any standard. Thus, when market rates rose above the usury ceiling, the number and volume of loans at the BRB were largely unaffected.

If there were no aggregate effects on lending behavior at the $\mathrm{BRB}$, did binding usury ceilings alter the composition of its portfolio? Columns 3 and 4 of Table 2 provide estimates of the effect on mean and median loan sizes. Consistent with the model of usury - that the more binding the usury ceiling, the bank will offer fewer small, high-rate loans, which will drive up the average loan size for a given aggregate value of loans - a one standard deviation increase in $R_{N Y}-R_{\text {limit }}$ led to a 4.57 percent increase in average loan size, or an increase from $\$ 498$ to $\$ 521$. Similarly, when the market rate rose above the usury ceiling, median loan size increased by a substantial amount. A one standard deviation increase in $\mathrm{R}_{\mathrm{NY}}-\mathrm{R}_{\text {limit }}$ led to an 8.76 percent increase in median loan size. In other words, average loan size was inelastic in the rate gap $(\varepsilon=0.6)$, but median loan size was elastic $(\varepsilon=1.1)$ in it. In this instance, the usury ceiling had a potentially larger detrimental effect on smaller, riskier 
borrowers. Rising interest rates closed some borrowers out as the bank sought larger, lower-risk loans.

The final two columns of Table 2 report estimates of the effect of market rates on loan maturities - a critical element of credit availability. Although the regression coefficient on average maturity is statistically insignificant, it carries the expected negative sign and implies that a one standard deviation in $\mathrm{R}_{\mathrm{NY}}-\mathrm{R}_{\text {limit }}$ decreased average loan maturity by 0.86 days or about 1 percent. For the median borrower, a similar increase in market and ceiling rates decreased the median maturity by nearly 2.5 days, or nearly 3 percent. In response to market rates in excess of the usury limit, the BRB offset legal and default risk by shortening the maturity structure of its loan portfolio. That its actions were larger for the median than the mean borrower, suggest that the effect of the ceiling rate was to diminish credit availability for smaller borrowers.

Thus, although increases in the market rate on short-term loans had a modest impact on the BRB's the total flow of new loans or the dollar value of new loans, such increases did influence loan size and loan maturities. Average loan size increased modestly and average maturity declined somewhat. The effect of high market rates was felt more by the median than by the mean borrower. Access to credit for the median borrower was more negatively effected by high market interest rates. Market rates above the usury limit induced the bank to adjust its portfolio in response to changing risks and rewards. It reduced loan sizes for small borrowers and increased loan sizes for large borrowers so that the overall effect was to increase average loan size and decrease maturities. Both changes worked to the detriment of smaller borrowers likely to find themselves in the usurious market. 


\subsection{Univariate Cross-sectional Analysis}

This section and the next makes use of 2,616 loans extended by the BRB in 1855. Given the earlier discussion about the bank and the local economy and because the national economy was approaching the end of a decade-long expansion, the bank's practices in 1855 should approximate equilibrium practice. The use of loans made in 1855 also allows the bank to have been in business long enough to have established extended relationships. The bank made 2,674 loans in 1855 to 978 different borrowers, but sundry details (typically interest charges or maturities) were missing for 58 loans, which are excluded from the analysis. ${ }^{16}$

The univariate analysis in Table 3 implies that usurious and nonusurious loans differed in several respects. Loans paying rates below the usury limit were larger, had longer maturities, were more likely to be bills of exchange payable in a distant commercial center, and were less likely to be extended in the first quarter of the fiscal year. Borrowers with established relationships with the bank were less likely to pay rates in excess of the usury limit, but it should be noted that the typical usurious loan involved a borrower who had a nearly four-year relationship with the bank and had borrowed on more than 25 previous occasions. Borrowers receiving their first loan from the bank were also somewhat more likely to pay a usurious rate. That these borrowers did not institute usury suits against the bank suggests that they were more interested in establishing a long-term relationship with the bank than in capturing the one-time gain from avoiding repayment. The historian, of course, is not privy to all the private information available to the banker, but the bankers at the BRB were apparently adept at distinguishing between borrowers who preferred a relationship (or a potential

\footnotetext{
${ }^{16}$ It is possible that the bankers purposely did not record interest charges on these loans to afford them some plausible deniability in the event a usury case was filed. There was, however, nothing notable or extraordinary about any of the other features of these loans.
} 
relationship) to a one-time gain from borrowing and suing.

Table 4 parses the data by whether the borrower had an existing relationship with the bank, that is, whether the current loan was the borrower's first. Consistent with the relationship literature, borrowers with an established relationship received larger loans, were less likely to pay a usurious rate, were more likely to draw on a bill of exchange rather than a promissory note, and were expected to provide less security (fewer endorsements) for their debt. First-time borrowers did not receive shorter loans, but they were more likely to borrow in the late spring or early summer, which was a slack time in the annual rhythm of the loan cycle. Thus, one element of credit availability - meeting peak seasonal demand - was strongly dependent on the existence of a prior relationship. The issue is the relative weight of the usury and relationship effects. Did the existence of a relationship encourage borrowers to pay market rates and allow them to avoid the costs of credit rationing?

\subsection{Multivariate Cross-Sectional Results: Loan Size}

Table 5 reports regression coefficients for each of the 12 combinations of three usury and four relationship proxies against the natural logarithm of the dollar value of the loan as the dependent variable. Studies of bank relationships have yet to settle on a consensus measure of the bankborrower relationship, but most use either a duration or an intensity measure. The four relationship measures used here capture different dimensions of the bank-borrower relationship. The variable Loans is equal to the number of previous loans the borrower had ever received from the bank between November 1845 and the present loan. Months measures relationship duration as the number of months between the date of first loan received by the borrower and the month of the current loan. Both measures are expected to be positively correlated with credit availability. The two measures 
need not be highly correlated (though the simple correlation coefficient is 0.58 ) as some borrowers borrowed intensively for a few months and never reappeared. Others borrowed once or a few times each year over a long period. Still others spaced their loans by several years. In the last instance, the information content of previous loans could be low if the useful half-life of information was short. To account for information decay, a third relationship variable, labeled Intensity and equal to [Months / Loans], is used as a relationship proxy. Because this value is larger for long relationships with few actual interactions, it is expected to be negatively correlated with the credit availability variables. Finally, a simple but crude independent variable, labeled Firstloan, is a binary variable equal to one if the current loan represents the borrower's first loan at the bank, and zero otherwise. Firstloan is expected to be negatively related to credit availability.

The reported regressions also include one of three separate usury measures. Rategap equals the loan rate minus the seven percent usury ceiling. ${ }^{17}$ This measure could take on values between -7 and infinity. It actually takes values between -4.64 and 19.89. The second measure, Extent of Usury, takes on the same value as Rategap if the loan rate exceeded the seven percent ceiling and zero otherwise. This measure treats all nonusurious loans equally, but recognizes that rates among usurious loans may vary a great deal. The third, and crudest, usury proxy is a dummy variable equal to one if the loan rate exceeded the seven percent ceiling and zero otherwise. The crime model of usury suggests that the three variables will be negatively related to credit availability. In addition to the variables of interest, each regression includes three dummy variables for bills of exchange

\footnotetext{
${ }^{17}$ All the regressions were also estimated using an $8 \%$ effective usury ceiling instead of the $7 \%$ value used here. Doing so did not change the results in any meaningful way. Indeed, parameter estimates using the 7 or $8 \%$ limit typically differed only in the third decimal place (thousandths). An $8 \%$ value was used as an alternative because bankers could legally charge customers collection and origination fees in addition to the legal $7 \%$ rate on certain bills of exchange. Because collection and origination fees were typically about one-fourth to one-half of a percentage point, legal rates could approach 7.5 and even $8 \%$.
} 
payable in New York City, Albany, or Boston and three quarterly dummy variables plus a constant.

Panel A of Table 5 reports the relevant coefficients for the Rategap usury proxy and each of the four relationship variables. The coefficients on the Rategap variable takes on the expected negative value, but are uniformly statistically insignificant. Similarly, Panel B of Table 5 reports negative but statistically insignificant coefficients on the Extent of Usury variable. The dummy variable Usury is negatively and significantly correlated with loan size. The coefficients on this relatively crude measure reveals that the typical usurious loan was between 20 and 23 percent smaller than the typically nonusurious loan. But grouping all usurious loans together treats potentially very different loans similarly. Even though coefficients on the Usury measure suggests a powerful effect, if we use the (admittedly insignificant) coefficients on the Extent of Usury variable and assume a borrower paid a rate of 8.87 percent (seven percent plus one standard deviation in the variable), this borrower's loan was just 0.06 percent smaller than a loan paying the statutory limit rate. Thus, the results suggest that the usury ceiling had a negligible effect on credit availability, once we control for the bank-borrower relationship. A handful of very small loans paid exorbitant rates, but these were not typical even among usurious loans.

Coefficients on the four relationship variables are uniformly significant and take on the expected signs and show that relationships had a much more powerful influence on credit availability than the usury ceiling. In regressions (1) and (5), for example, the coefficients on the Loans variable imply that having borrowed one additional time from the bank increased loan size by about 0.5 percent. These coefficients imply that the average borrower with 34.1 previous loans received a loan 17 percent larger than a first-time borrower. Similarly, the coefficients on the Months variable in regressions (2) and (6) imply that increasing the relationship by one month increased loan size by 
0.2 percent. With the average relationship having persisted for 49.6 months, the relationship effect was economically meaningful because a one standard deviation increase in the length of a relationship led to an 8.6 percent increase in loan size.

The regression coefficients on Intensity and Firstloan are consistent with the other relationship variables. A one unit increase in Intensity (months/loan) decreased loan size by 1.3 percent. Borrowers receiving their first loan from the bank typically received a loan between 66.7 and 67.3 percent as large as borrowers having an existing relationship with the bank. Firstloan, however, is a crude measure of the bank-borrower relationship. The three continuous variables provide more nuanced interpretations. Nevertheless, the coefficients on Firstloan highlight the importance of a relationship. First time borrowers had access to much less bank credit than known borrowers.

\subsection{Multivariate Cross-Sectional Results: Loan Maturity}

Loan size was just one component of credit availability of interest to borrowers. In addition to the size of a loan, borrowers were also concerned with the maturity of the loan. In some instances, access to larger volumes of credit was of limited value if the bank was willing to extend it only for short periods. Table 6 reports three panels of regressions where the dependent variable is equal to the natural logarithm of the loan maturity in days. As in the previous analysis, all the regressions included three dummy variables for bills of exchange payable in New York City, Albany, and Boston and three quarterly dummy variables, plus a constant.

Time-series results reported in Section 5.1 reveal that when market rates rose above the usury limit loan maturities declined. The cross sectional results on individual loans from 1855 reveal a 
similar effect. As the regressions in Panel A and B show, loans paying rates in excess of the seven percent ceiling matured more quickly than loans paying sub-usurious rates. Using the estimated coefficients on Rategap in Panel A, the regression results imply that a loan paying one standard deviation more than the average rate matured in 90.3 percent of the time given to a loan paying the average rate. Similarly, estimated coefficients on Extent of Usury imply that a loan paying a rate one standard deviation greater than the average rate matured in 89.9 percent of the time given to a loan paying the average rate. Coefficients on the binary Usury measure in Panel C suggest that the average usurious loan ran for 94.2 percent of the time given to nonusurious loans.

As with loan size, relationships provided a counterweight to the negative usury effects on loan maturity. According the estimates in all three panels of Table 6, a borrower who had a lending relationship (Loans) one standard deviation larger than the average received loans with an average 5.9 percent longer maturity. A borrower with a relationship that had lasted, in terms of months, one standard deviation longer than the average received loans with maturities 4.3 percent longer. Interestingly, less intense relationships were rewarded with longer maturities. Given the variable's definition (months/loans), this result implies having maintained a long relationship was better for receiving loans at longer maturities than having borrowed often, though each separately mattered. This may reflect a survival premium. Even though the borrower had not maintained an intensive or, perhaps, an exclusive relationship with the bank, he or she could receive credit on better terms because his or her firm had been in business for a longer period.

\subsection{Joint Determination of Loan Size, Loan Maturity, and Loan Rates}

The multivariate analyses in sections 5.3 and 5.4 assume that loan amounts and loan maturities can 
be modeled separately. It is possible, even probable, that bankers negotiated the three margins observable in this data - loan amount, loan maturity, and the interest rate - simultaneously. If the three features were not determined independently, estimating the effects as if they were may provide a biased estimate of the effects of the independent variables. One solution to this is to estimate the model jointly using Seemingly Unrelated Regression (SUR) techniques, especially if the disturbances across the equations are correlated (Greene 1990).

The difficulty in estimating a multiple-equation model is specifying a system of equations that will improve on the OLS estimates previously reported. If each equation of a three-equation system uses the same independent variables, the resulting generalized least squares (GLS) coefficient estimates are the same as those obtained by ordinary least squares (OLS). Fortunately, the bank's records provide some additional data that can be used to estimate a three-equation model so that each equation contains some different variables. Each equation of the three equation model includes three indicator variables for bills of exchange payable in New York City, Albany, or Boston (the excluded category is locally payable promissory notes); and, three quarterly indicator variables (the excluded quarter is winter). Each equation also includes one of the relationship measures (number of prior loans, length of relationship in months, relationship intensity, and whether the loan is a first loan). The loan amount equation includes the RATEGAP variable. The Loan maturity equation includes the RATEGAP variable, plus the number of consignors to the loan. And the rategap equation includes the current market rate on commercial paper in New York City, as well as whether the loan was renewed at maturity. The three equation system takes the following form:

(1) Loan amount $=\mathrm{f}_{1}(\mathrm{NYC}$, Albany, Boston, Q1, Q2, Q3, Rategap, Relationship)

(2) Loan maturity $=\mathrm{f}_{2}$ (NYC, Albany, Boston, Q1, Q2, Q3, Rategap, Endorsers, Relationship) 
(3) Rategap $=\mathrm{f}_{3}(\mathrm{NYC}$, Albany, Boston, Q1, Q2, Q3, Market rate, Renewal, Relationship)

Because the regressors in all three equations are similar, the efficiency gains provided by the SUR procedures are likely to be small, but it is nevertheless important to correct for correlations in the disturbance terms to the extent that the data allow.

The regressions are estimated using the 2,616 loans extended by the bank in 1855 . The results are generally in accord with expectations and the systems are reasonably well specified (p-values on the goodness-of-fit $\chi^{2}$ statistics are all between 0.0036 and 0.0000 ). Table 7 presents the results for the variables of interest. The coefficient estimates for the common indicator variables are not reported, but were nearly all statistically significant in the loan amount and maturity equations; less so for the Rategap equation.

Estimating the equations as a system rather than independently does not lead to any substantially different conclusions than those implied by the OLS parameter estimates. ${ }^{18}$ First, longer or more intense relationships did not have substantive effects on interest rates. The one exception is that longer relationships (Months) led to marginally lower interest rates, but as previously mentioned the Months variable may be capturing a longevity effect. The longer the relationship, the longer the business had been in operation, which may have led to greater confidence on the banker's behalf that the business would be around to repay its loans.

Consider the Loan Amount equation estimates. The SUR estimates on the interest rate and relationship variables are comparable in magnitude and statistical significance to the OLS estimates.

\footnotetext{
${ }^{18}$ Indeed, p-values on correlation tests on the disturbance terms suggest that several, but not all, the equations are independent. This is why the SUR and OLS coefficient estimates are not substantially different.
} 
Indeed, the Rategap variable is small and statistically insignificant in all four specifications. The relationship variables are all statistically significant and are generally economically meaningful, implying that relationships had greater influences on credit availability than the usury ceiling. In column (1), for instance, the estimated coefficient on the Loans variable implies that having received one additional prior loan increased loan size by nearly 0.5 percent. Similarly, the coefficient on Months suggests that a having maintained a relationship for one additional month increased the dollar value of a loan by 0.2 percent. A borrower receiving his or her first loan, typically received about 40 percent less than borrowers with a prior borrowing relationship.

A usury ceiling had a greater influence on loan maturity than on loan amount. As in the OLS estimates, the coefficients on the Rategap variable are economically meaningful and statistically significant. The estimated coefficient in Eq. 2, Column(1) implies that a loan paying one percentage point more than the usury limit matured in 92 percent of the time of the average loan. Relationships had smaller influences on loan maturities than on loan amounts. Again, according to the parameter estimate on the Loans variable in Eq. 2, Column (1) implies that had a borrowing relationship one standard deviation longer than average received a loan with about 4.1 percent more days to maturity. Estimated coefficients on the other relationship variables lead to similar conclusions.

Taken together, the univariate and multivariate cross-sectional results highlight two features of bank lending: (1) that the BRB honored the usury law in something more than the breach, but it was not afraid of charging extra-usurious rates to all kinds of customers when market rates exceeded the statutory limit; and (2) the usury ceiling had little practical effect on credit availability at the BRB once relationship duration and intensity are controlled for. Loan maturities declined during high-rate periods and when the characteristics of the loan called for a rate in excess of the usury ceiling, but 
there were no meaningful effects of usurious rates on loan size.

\section{Concluding Remarks}

Usury limits are often held up as a form of potentially costly financial repression. According to the McKinnon (1973) and Shaw (1973) critique, restrictions on financial transactions and burdensome regulations reduce the attractiveness of holding claims on the domestic banking sector and, thereby, reduce the profitability of providing intermediation services. Financially repressed economies are adversely affected in a number of ways, but mostly because repression leads to a decrease in the flow of loanable funds through the sector, interest rates that can vary arbitrarily from one class of borrowers to another, and precludes financial deepening outside the banking sector (Espinosa and Hunter 1994). In short, measures that repress the financial sector lead to inefficient credit rationing which slows economic growth.

The evidence from this one bank at this one point in time, at least, suggest that a usury law that prescribed severe civil and criminal penalties had little practical effect on lending behavior other than the general effect that high-risk borrowers were rationed when interest rates rose substantially above the usury ceiling. Relationships between borrowers and lenders had a more powerful positive influence on credit availability than the usury limit had a negative influence. To the extent that it is safe to generalize from this example, we may conclude that the economic development of the antebellum United States was not inhibited by state usury laws. But, of course, the issue merits further attention.

Finally, one implication from this analysis is that it may be wise to establish a usury limit and prescribe severe penalties for egregious violations of social standards of equitable treatment, but not 
interfere much in mutually beneficial transactions between parties committed to maintaining a continuing and nonexploitive relationship. The above analysis shows that usury limits were not strictly observed, but rates were not arbitrarily determined by unobservable characteristics. Indeed, loan and market characteristics explain much of the variation in individual loan rates. In the end, this explains why borrowers were reluctant to file usury suits even when they were charged usurious rates. The relationship was valuable and the transaction was mutually beneficial. Future research should continue to investigate how implicit agreements between borrowers and lenders may mitigate the worst aspects of financially repressive measures.

\section{References}

Avio, Kenneth L. “An Economic Rationale for Statutory Interest Rate Ceilings.” Quarterly Review of Economics and Business 13:3 (Autumn 1973), 61-72.

Albany Argus, various dates.

Becker, Gary S. “Crime and Punishment: An Economic Approach.” Journal of Political Economy 76:2 (March 1968), 169-217.

Black River Bank. Discount Books 2 and 3. (1845-1859). Jefferson County (New York) Historical Society. Watertown, New York.

Blitz, Rudolph C. and Millard F. Long. “The Economics of Usury Regulation.” Journal of Political Economy 73:6 (December 1965), 608-619. 
Blydenburgh, J. W. A Treatise on the Law of Usury; To Which Are Added, the Statutes of the Several States Relating to Interest Now in Force: Together with a Digest of All the Decisions, and an Index to the Reported Adjudications from the Statute of Henry VIII to the Present Time. New York: John S. Voorhies, 1844.

Bodenhorn, Howard. "Capital Mobility and Financial Integration in Antebellum America." Journal of Economic History 52:3 (September 1992), 585-610.

Bodenhorn, Howard. History of Banking in Antebellum America: Financial Markets and Economic Development in an Age of Nation Building. Cambridge and New York: Cambridge University Press, 2000.

Bodenhorn, Howard. "Short-Term Loans and Long-Term Relationships: Relationship Lending in Antebellum America.” Journal of Money, Credit, and Banking 35:4 (August 2003), 485-506.

Bodenhorn, Howard. "Bank Chartering and Political Corruption in Antebellum New York: Free Banking as Reform." In Corruption and Reform: Lessons from America's History. Edited by Edward Glaeser and Claudia Golding. Chicago: University of Chicago Press (forthcoming 2006).

Boot, Arnoud W. A. "Relationship Banking: What Do We Know?" Journal of Financial Intermediation 9:1 (January 2000), 7-25.

Boyes, W. J. and Dale Beck Furnish. "A Note on the Use of Incorporation as an Escape from Usury Ceilings." Journal of Industrial Economics 32:3 (March 1984), 367-372.

Davis, Lance E. "The New England Textile Mills and the Capital Markets: A Study of Industrial Borrowing, 1840-1860.” Journal of Economic History 20:1 (March 1960), 1-30.

Elsas, Ralf. "Empirical Determinants of Relationship Lending." Journal of Financial Intermediation 
14:1 (January 2005), 32-57.

Elyasiani, Elyas and Lawrence G. Goldberg. "Relationship Lending: A Survey of the Literature." Journal of Economics and Business 56:4 (2004), 315-330.

Emerson, E. C. (editor). Our Country and Its People: A Descriptive Work on Jefferson County, New York from 1793 to 1894. Boston: Boston History Company, 1898.

Espinosa, Marco and William C. Hunter. "Financial Repression and Economic Development." Federal Reserve Bank of Atlanta Economic Review 79:5 (September/October 1994), 1-11.

Glaeser, Edward L. "An Overview of Crime and Punishment.” Working paper, Harvard University (March 1999).

Glaeser, Edward L. and José Scheinkman. "Neither a Borrower Nor a Lender Be: An Economic Analysis of Interest Restrictions and Usury Laws." Journal of Law and Economics 41:1 (April 1998), 1-36.

Hammond, Bray. Banks and Politics in America from the Revolution to the Civil War. Princeton: Princeton University Press, 1957.

Horowitz, Morton J. The Transformation of American Law: 1780-1860. Cambridge, Mass.: Harvard University Press, 1977.

Jaffee, Dwight M. and Franco Modigliani. "A Theory and Test of Credit Rationing." American Economic Review 59:5 (December 1969), 850-72.

Kahn, James A. "Another Look at Free Banking in the United States." American Economic Review 75:4 (September 1985), 881-85.

Masciandaro, Donato. "In Offense of Usury Laws: Microfoundations of Illegal Credit Contracts." European Journal of Law and Economics 12:3 (November 2001), 193-215. 
Masciandaro, Donato. "Why Shylock Can Be Efficient: A Theory of Usury Contracts.” Kredit und Kapital 35:3 (March 2002), 381-399.

McKinnon, Ronald I. Money and Capital in Economic Development. Washington, D.C.: The Brookings Institution, 1973.

Nathan, Harold C. "Economic Analysis of Usury Laws." Journal of Bank Research 10:4 (Winter 1980), 200-211.

New York State. Assembly. "Annual Report of the Superintendent of the Banking Department." Doc. No. 4. Assembly Documents (1856), Volume 2.

New York State. Assembly. "Annual Report of the Superintendent of the Banking Department." Doc. No. 3. Assembly Documents (1862), Volume 2.

New York. State. Senate. "Report of the Select Committee on the Subject of Usury." Doc. No. 40. Senate Documents (1851), Volume 2.

New York Times, 10 March 1852.

Ongena, Steven and David C. Smith. "Bank Relationships: A Review.” In Performance of Financial Institutions: Efficiency, Innovation, Regulation, pp. 221-258. Edited by Patrick T. Harker and Stavros A. Zenios. Cambridge and New York: Cambridge University Press, 2000.

Ostas, James R. "Effects of Usury Ceilings in the Mortgage Market." Journal of Finance 31:3 (June 1976), 821-834.

Peterson, Richard L. "Usury Laws and Consumer Credit: A Note." Journal of Finance 38:4 (September 1983), 1299-1304.

Rajan, Raghuram G. "Insiders and Outsiders: The Choice between Informed and Arm's Length Debt.” Journal of Finance 47:4 (September 1992), 1367-1400. 
Redlich, Fritz. The Molding of American Banking: Men and Ideas. New York: Johnson Reprint Company, 1968.

Reed, Clyde G. and Cliff T. Bekar. "Religious Prohibitions Against Usury.” Working paper, Simon Fraser University (July 2002).

Riemersma, Jelle C. "Usury Restrictions in a Mercantile Economy." Canadian Journal of Economics and Political Science 18:1 (February 1952), 17-26.

Rockoff, Hugh. "Prodigals and Projectors: An Economic History of Usury Laws in the United States from Colonial Times to 1900.” NBER working paper 9742 (May 2003).

Romano, Mary Ann. "Law, Politics, and the Economy: Changing Patterns of Growth in DebtorCreditor Laws, New York State, 1785-1860.” Ph. D. dissertation, New York University, 1989.

Sharpe, Steven A. "Asymmetric Information, Banking Lending and Implicit Contracts: A Stylized Model of Customer Relationships." Journal of Finance 45:4 (September 1990), 1069-1087.

Shaw, Edward S. Financial Deepening in Economic Development. New York and Oxford: Oxford University Press, 1973.

Stiglitz, Joseph E. “The Causes and Consequences of the Dependence of Quality on Price.” Journal of Economic Literature 25:1 (March 1987), 1-48.

Temin, Peter and Hans-Joachim Voth. "Financial Repression in a Natural Experiment: Loan Allocation and the Change in the Usury Laws in 1714." Working paper, undated.

Tucillo, John. "Taxation by Regulation: The Case of Financial Intermediaries." Bell Journal of Economics 8:2 (Autumn 1977), 577-587.

United States. Census Office. $7^{\text {th }}$ Census (1850). Statistical View of the United States. Washington, 
D.C.: Beverly Tucker, 1854.

United States. Census Office. $8^{\text {th }}$ Census (1860). Statistics of the United States. Washington, D.C.: Government Printing Office, 1866.

Villegas, Daniel J. "The Impact of Usury Ceilings on Consumer Credit." Southern Economic Journal 56:1 (July 1989), 126-141.

Von Thadden, Ernst-Ludwig. "Long-Term Contracts, Short-Term Investment, and Monitoring." Review of Economic Studies 62:4 (October 1995), 557-575.

Wolken, John D. and Frank J. Navratil. "The Economic Impact of the Federal Credit Union Usury Ceiling." Journal of Finance 36:5 (December 1981), 1157-1168.

Wright, Robert E. Hamilton Unbound: Finance and the Creation of the American Republic. Westport, Conn.: Greenwood Press, 2002. 
Figure 1: Total Monthly Lending Volume at the Black River Bank, November 1845 to April 1859

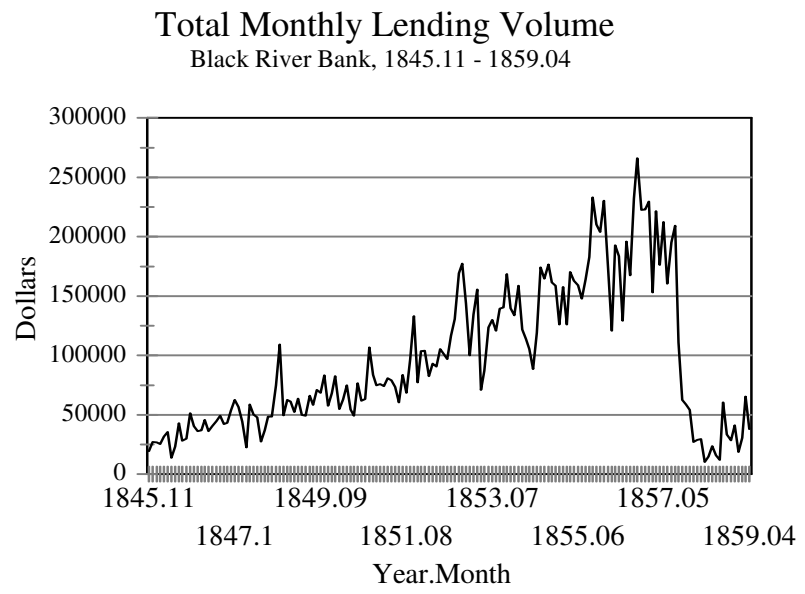

Figure 2: Average and Median Loan Rates at the Black River Bank, November 1845 to April 1859

Average and Median Loan Rates (\%)

Black River Bank, 1845.11 - 1859.04

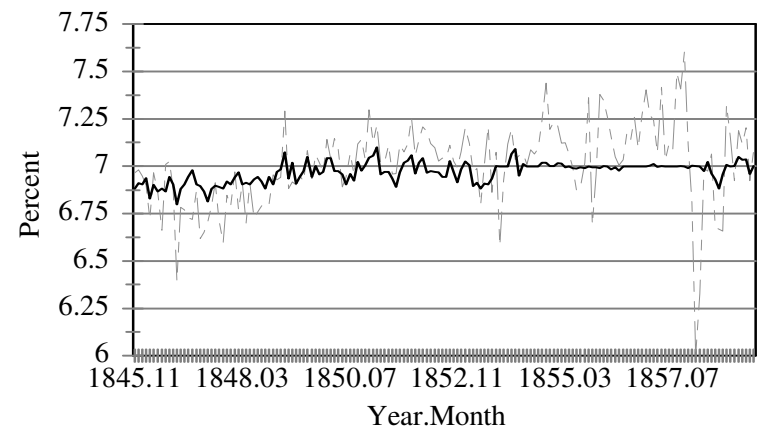

Average — Median 
Table 1: Frequency Distribution of Interest Rates on Loans at the Black River Bank, 1845-1859

\begin{tabular}{ll}
\hline $\begin{array}{l}\text { Interest } \\
\text { Rate } \\
\text { Interval }\end{array}$ & $\begin{array}{l}\text { Number } \\
\text { of } \\
\text { Loans }\end{array}$ \\
\hline $0-0.99 \%$ & 15 \\
$1-1.99$ & 5 \\
$2-2.99$ & 28 \\
$3-3.99$ & 49 \\
$4-4.99$ & 144 \\
$5-5.99$ & 248 \\
$6-6.99$ & 16,447 \\
$7-7.99$ & 10,905 \\
$8-8.99$ & 540 \\
$9-9.99$ & 272 \\
$10-10.99$ & 161 \\
$11-11.99$ & 74 \\
$12-12.99$ & 52 \\
$13-13.99$ & 43 \\
$14-14.99$ & 19 \\
$15+$ & 74 \\
\hline
\end{tabular}

Sources: Black River Bank, Discount Book \#2; Discount Book \#3. 
Table 2: Effects of usury limit on volume of loans, loan size, and loan maturity

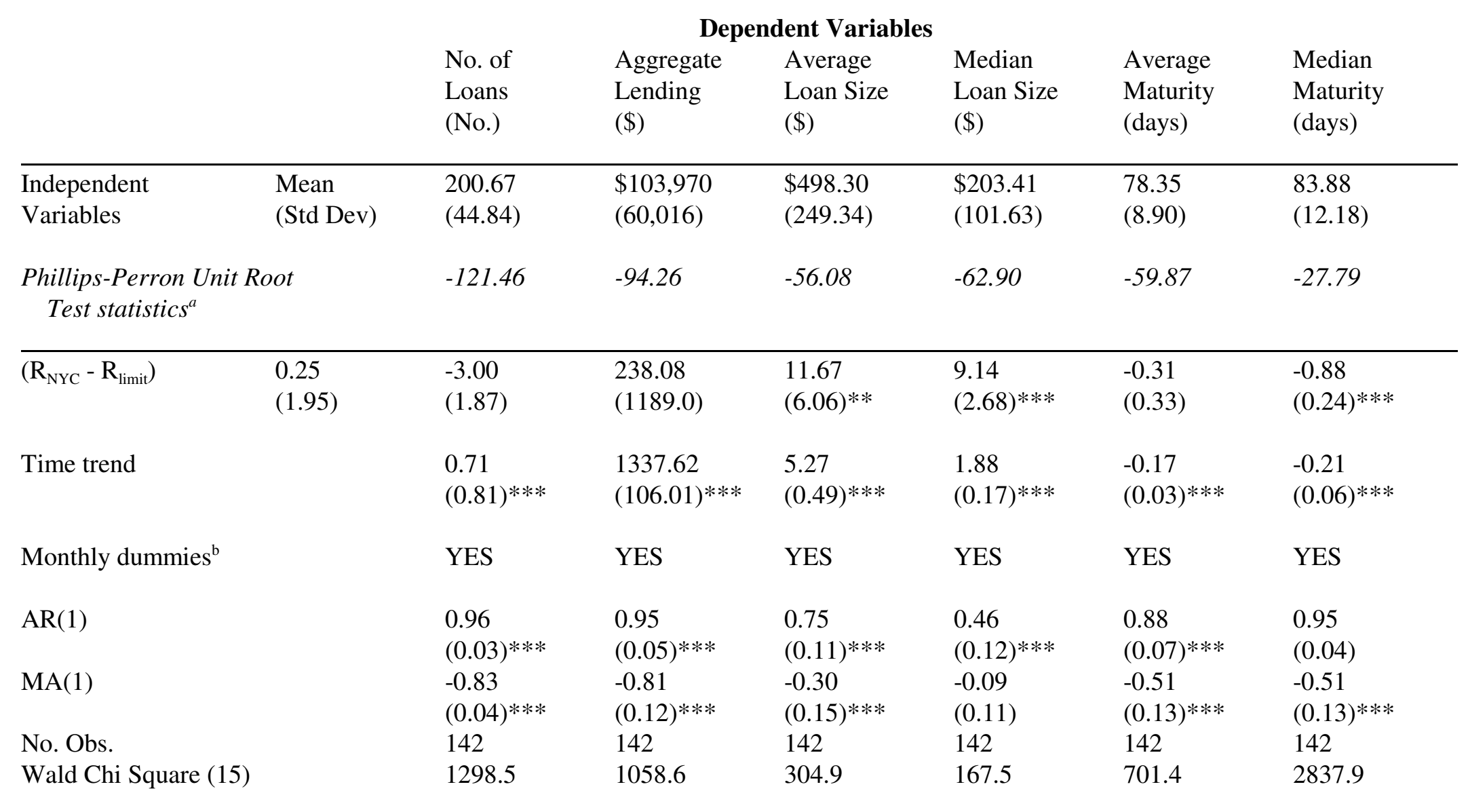

Notes: ${ }^{\text {a }}$ regressions included a time trend. The $1 \%$ critical value for all regressions is -27.67 . The null hypothesis of a unit root is rejected for each series. ${ }^{\mathrm{b}}$ December is the excluded month. The January through July dummies tend to be statistically significant; October and November dummies are rarely significant; others sometimes are. Standard errors are semi-robust White heteroskedastic errors. 
Table 3: Descriptive statistics for usurious and nonusurious loans

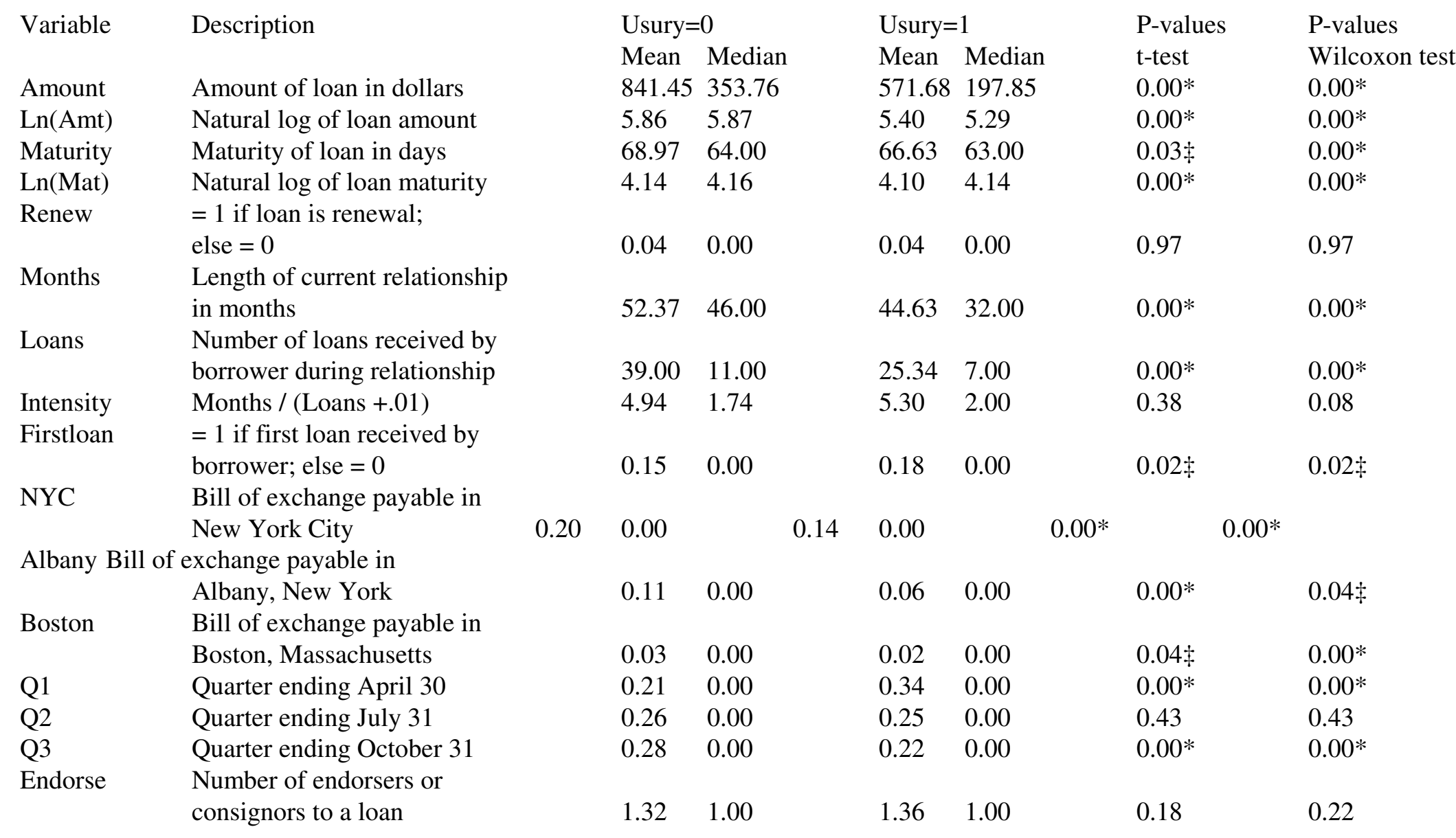

Notes: Means and medians are based on 2,616 loans granted by the bank in 1855, separated by interest rates where the usury ceiling was 7 percent. P-values of t-test are levels of significance for simple t-tests on differences in means. P-value on Wilcoxon statistic is significance level on nonparametric Wilcoxon signed-rank test. Sources: Black River Bank (1845-1859). 
Table 4: Descriptive statistics for relationship and non-relationship loans

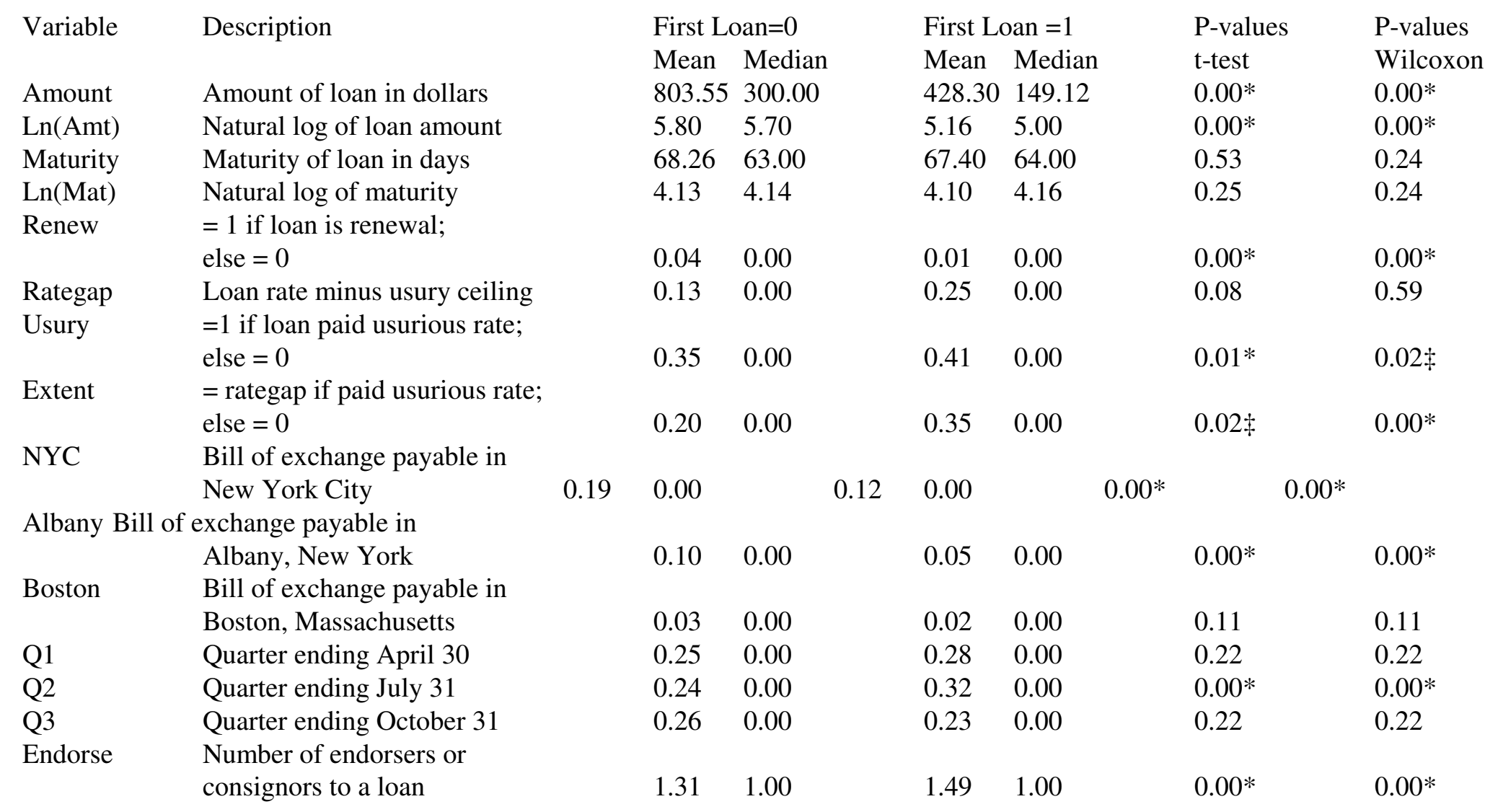

Notes: Means and medians are based on 2,616 loans granted by the bank in 1855, separated by interest rates where the usury ceiling was 7 percent. P-values of t-test are levels of significance for simple t-tests on differences in means. P-value on Wilcoxon statistic is significance level on nonparametric Wilcoxon signed-rank test.

Sources: See Table 1. 
Table 5: Effects of usury and relationships on credit availability

Dependent variable in OLS regressions = natural log of loan amount

\begin{tabular}{|c|c|c|c|c|}
\hline Panel A. & (1) & (2) & (3) & (4) \\
\hline Rategap & $\begin{array}{l}-0.003 \\
(0.02)\end{array}$ & $\begin{array}{l}-0.002 \\
(0.02)\end{array}$ & $\begin{array}{l}-0.010 \\
(0.020)\end{array}$ & $\begin{array}{l}-0.004 \\
(0.020)\end{array}$ \\
\hline Loans & $\begin{array}{l}0.005 \\
(0.000)^{*}\end{array}$ & & & \\
\hline Months & & $\begin{array}{l}0.002 \\
(0.000)^{*}\end{array}$ & & \\
\hline Intensity & & & $\begin{array}{l}-0.013 \\
(0.002)^{*}\end{array}$ & \\
\hline Firstloan & & & & $\begin{array}{l}-0.405 \\
(0.054) *\end{array}$ \\
\hline Panel B. & $(5)$ & (6) & (7) & (8) \\
\hline Extent of Usury & $\begin{array}{l}-0.009 \\
(0.021)\end{array}$ & $\begin{array}{l}-0.009 \\
(0.022)\end{array}$ & $\begin{array}{l}-0.018 \\
(0.022)\end{array}$ & $\begin{array}{l}-0.009 \\
(0.021)\end{array}$ \\
\hline Loans & $\begin{array}{l}0.005 \\
(0.000)^{*}\end{array}$ & & & \\
\hline Months & & $\begin{array}{l}0.002 \\
(0.000)^{*}\end{array}$ & & \\
\hline Intensity & & & $\begin{array}{l}-0.013 \\
(0.057)^{*}\end{array}$ & \\
\hline Firstloan & & & & $\begin{array}{l}-0.404 \\
(0.054)^{*}\end{array}$ \\
\hline Panel C. & $(9)$ & (10) & (11) & (12) \\
\hline Usury & $\begin{array}{l}-0.226 \\
(0.042)^{*}\end{array}$ & $\begin{array}{l}-0.245 \\
(0.044)^{*}\end{array}$ & $\begin{array}{l}-0.258 \\
(0.043)^{*}\end{array}$ & $\begin{array}{l}-0.248 \\
(0.044)^{*}\end{array}$ \\
\hline Loans & $\begin{array}{l}0.005 \\
(0.000)^{*}\end{array}$ & & & \\
\hline Months & & $\begin{array}{l}0.002 \\
(0.000)^{*}\end{array}$ & & \\
\hline Intensity & & & $\begin{array}{l}-0.013 \\
(0.002)^{*}\end{array}$ & \\
\hline Firstloan & & & & $\begin{array}{l}-0.396 \\
(0.054) *\end{array}$ \\
\hline
\end{tabular}

Notes: All regressions based on 2,616 observations. All regressions include three dummy variables for bills of exchange payable in commercial centers and three quarterly dummy variables. All regressions have adjusted R-squares of 0.36 or higher; and all have F(8, 2607) in excess of 200. See Tables 2 and 3 for descriptions of the independent variables. Robust standard errors in parentheses. ${ }^{*}$ signifies statistical significance at $1 \%$. 
Table 6: Effects of usury and relationships on credit availability

Dependent variable in OLS regressions = natural log of loan maturity

\begin{tabular}{|c|c|c|c|c|}
\hline Panel A. & (1) & (2) & (3) & (4) \\
\hline Rategap & $\begin{array}{l}-0.085 \\
(0.009) *\end{array}$ & $\begin{array}{l}-0.083 \\
(0.009)^{*}\end{array}$ & $\begin{array}{l}-0.085 \\
(0.009)^{*}\end{array}$ & $\begin{array}{l}-0.085 \\
(0.009) *\end{array}$ \\
\hline Loans & $\begin{array}{l}0.001 \\
(0.000)^{*}\end{array}$ & & & \\
\hline Months & & $\begin{array}{l}0.001 \\
(0.000)^{*}\end{array}$ & & \\
\hline Intensity & & & $\begin{array}{l}0.002 \\
(0.001) \ddagger\end{array}$ & \\
\hline Firstloan & & & & $\begin{array}{l}-0.045 \\
(0.026)\end{array}$ \\
\hline Panel B. & $(5)$ & $(6)$ & $(7)$ & $(8)$ \\
\hline Extent of Usury & $\begin{array}{l}-0.091 \\
(0.009)^{*}\end{array}$ & $\begin{array}{l}-0.089 \\
(0.009)^{*}\end{array}$ & $\begin{array}{l}-0.091 \\
(0.010)^{*}\end{array}$ & $\begin{array}{l}-0.091 \\
(0.010)\end{array}$ \\
\hline Loans & $\begin{array}{l}0.001 \\
(0.000)^{*}\end{array}$ & & & \\
\hline Months & & $\begin{array}{l}0.001 \\
(0.000)^{*}\end{array}$ & & \\
\hline Intensity & & & $\begin{array}{l}0.002 \\
(0.001) \neq\end{array}$ & \\
\hline Firstloan & & & & $\begin{array}{l}-0.042 \\
(0.026)\end{array}$ \\
\hline Panel C. & (9) & (10) & $(11)$ & (12) \\
\hline Usury & $\begin{array}{l}-0.059 \\
(0.020)^{*}\end{array}$ & $\begin{array}{l}-0.056 \\
(0.020)^{*}\end{array}$ & $\begin{array}{l}-0.063 \\
(0.020)^{*}\end{array}$ & $\begin{array}{l}-0.062 \\
(0.020)^{*}\end{array}$ \\
\hline Loans & $\begin{array}{l}0.001 \\
(0.000)^{*}\end{array}$ & & & \\
\hline Months & & $\begin{array}{l}0.001 \\
(0.000)^{*}\end{array}$ & & \\
\hline Intensity & & & $\begin{array}{l}0.002 \\
(0.000) \ddagger\end{array}$ & \\
\hline Firstloan & & & & $\begin{array}{l}-0.050 \\
(0.027)\end{array}$ \\
\hline
\end{tabular}

Notes: All regressions based on 2,616 observations. All regressions include three dummy variables for bills of exchange payable in commercial centers and three quarterly dummy variables. All regressions have adjusted R-squares between 0.08 and 0.13 or higher; and all have $F(8,2607)$ in excess of 39. See Tables 2 and 3 for descriptions of the independent variables. Robust standard errors in parentheses. * signifies statistical significance at $1 \%$; and $\$$ signifies significance at $5 \%$. 
Table 7: Effects of usury and relationships on loan terms: Seemingly Unrelated Regression estimates

(1)

Eq.1 Loan amount

Rategap

Loans

Months

Intensity

Firstloan

$\underline{\text { Eq. } 2 \text { Loan maturity }}$

Rategap

Loans

Months

Intensity

Firstloan

Eq. 3 Rategap

Loans

Months

Intensity

Firstloan
(2)

(3)

(4)

$-0.0027$

$-0.0025$

(0.017)

0.0046

$(0.0004)^{*}$

0.0023

$(0.0005)^{*}$

$-0.0133$

$(0.002)^{*}$

$-0.4047$

$(0.057)^{*}$

-0.0856
$(0.007)^{*}$
0.0006
$(0.0002)^{*}$

$-0.0839$

$(0.007)^{*}$

$-0.0857$

$(0.007)^{*}$

$-0.0857$

(0.007)*

0.0011

$(0.007)^{*}$

0.0018

(0.0008)末

$-0.0509$

(0.024)

$-0.0005$

(0.0004)

$-0.0017$

$(0.0005)^{*}$
$-0.0034$

(0.002)

0.0897

(0.065)

Notes: All regressions based on 2,616 observations. Equations (1) - (3) include three dummy variables for bills of exchange payable in commercial centers and a constant. Equations (1) - (2) include three quarterly dummy variables. Equation (2) also includes the number of endorsers. Equation (3) also includes the current commercial paper rate and whether the loan is a renewal. See Tables 2 and 3 for descriptions of the independent variables. Robust standard errors in parentheses. * signifies statistical significance at $1 \%$; and $\$$ signifies significance at $5 \%$. 